\title{
Toxicity and Compound Identification of Padinaaustralis Extract
}

\author{
Tri Saptari Haryani, Bina Lohitasari, Triastinurmiatiningsih
}

\begin{abstract}
People awareness of the importance of health has increased significantly in the last decade, it forces people to find alternative treatments which are cheaper and safer when compared with the use of synthetic drugs. Research on antibacterial activity of Padina australis against Escherichia coli have been conducted, but it does not identified yet which active compounds in the Padina australis extract that has potential as an antibacterial. Identification phytol compounds from the extracts of Padina australis and toxicity tests have been conducted using BSLT and GCMS methods. The results of this research identify that Padina australis extract with ethanol has antibacterial activity value of $L_{50} 177.83$ ppm. Phytochemical test results show that active ingredient of Padina australis extract is terpenoid compounds, and that triterpenoids has potential as an antibacterial. GC-MS test result shows that active compound of Padina australis extract consists of phytol compound which has $\mathbf{9 0 - 9 9 \%}$ similarity with steroids, phenols, fatty acids, carboxylic acids, hydrocarbons, and proteins. Compound identification test of active Padina australis extracts through GC-MS methods show that phytol compounds are useful as antibacterial and the toxicity test results show that phytol compounds are not cytotoxic.
\end{abstract}

Index Terms: Antibacterial, Extract Padina Australis, LC $_{50}$.

\section{INTRODUCTION}

People awareness of the importance of health has increased significantly in the last decade [1]. It forces the public to find an alternative treatment that is economically cheaper and safer when compared with the use of synthetic drugs. Many people change their lifestyle by going back to nature and use medicines from natural ingredients. As an island country with coastline length of $81,000 \mathrm{~km}$, Indonesia is an enormous source of many natural resources. In spite of that, land-based plant's properties still tend to be explored more than water-based or sea-based plant's, including seaweed's. According to Rasyid (2004), several species of seaweed in Indonesia can be used as a medicine, but it is currently experiencing problems because the research is not developed yet [2]. Therefore, the use of seaweed as medicine is still limited. The research conducted by [3] showed that Padinaaustralis, has antibacterial activity against Escherichia coli, but which bioactive compounds from the extracts of Padinaaustralis that has potential as an antibacterial has not been tested.

Revised Manuscript Received on April 25, 2019.

Tri Saptari Haryani, Department of Biology, Pakuan University, Indonesia.

Bina Lohitasari, Department of Pharmacy, Pakuan University, Indonesia.

Triastinurmiatiningsih, Department of Biology, Pakuan University, Indonesia.
Padinaaustralis is a seaweed that comes from the class of Phaeophyceae (brown seaweed). Padinaaustralis can be found on rocky and choppy coasts. This seaweed contains fucoxanthin (brown), violaxanthin, chlorophyll a, chlorophyll c, $\beta$-carotene, and xanthophyll pigments. In pharmaceutical industry, algin or alginic acid from Padinaaustralis is used to make pills, ointments, toothpaste, lotions, and creams [4]. Fucoxanthin is part of carotenoid with formula $\mathrm{C} 42 \mathrm{H} 58 \mathrm{O} 6$. This pigment is found in some types of brown algae, including Padinaaustralis. Based on [5], fucoxanthin has the ability as an anti-carcinogenic, antibacterial, anti-inflammatory, protecting cells against harmful ingredients such as $\mathrm{H} 2 \mathrm{O} 2$, and free-radical scavengers or antioxi-dants. As a health food supplement, fucoxanthin has been shown to have no toxic properties [6]. Testing the activity and toxicity of plant extracts can be done using Brine Shrimp Lethality Test (BSLT), the method used to isolate the bioactive compounds of plant extracts. BSLT method is often utilized in a preliminary test for screening or to screen pharmacological activity of medicinal plants to support the use of medicinal plants in traditional and modern treatment. It is also utilized to detect toxic effects of fungi, the toxicity of the plant extract, heavy metals, pesticides and cytotoxicity [7]-[8]. Meanwhile, to identify active compounds in a material, GC-MS method (Gas Chromatography Mass Spectrophotometry) is utilized. It is a method used to identify a compound contained in the gas mixture and also to determine the concentration of a substance in gas phase.

\section{MATERIALS AND METHODS}

Identification of the active compound and Padinaaustralis toxicity extract tests were conducted in Bogor Agriculture Institute's Laboratory of Microbiology and University of Pakuan's Laboratory of Pharmacy, both located in Bogor. Materials that were used for this research are Padinaaustralis seaweed from Coastal Waters of Bayah, Banten, distilled water, ethanol $96 \%$, materials for phytochemical test, and substances for GC-MS and BSLT tests. Tools used in this research are a set of GCMS (Gas Chromatography Mass Spectrophotometry) tools to identify active compounds inside Padinaaustralis extract, a set of BSLT (Brine Shrimp Lethality test) method toxicity test tools, and glass tools and other tools commonly used in microbiology laboratory and pharmacy.

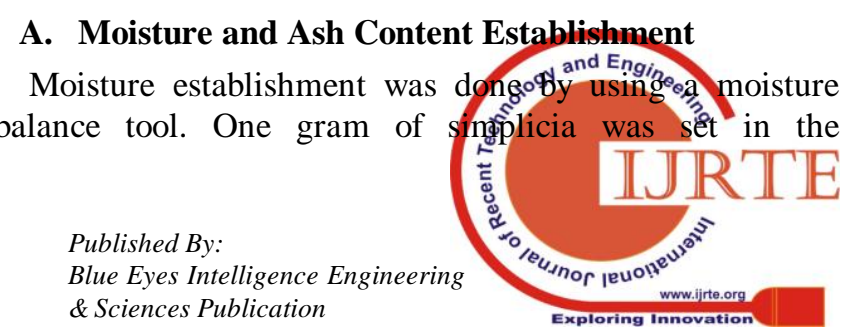


temperature of $105^{\circ} \mathrm{C}$ for 10 minutes, and then the moisture content is measured. The result is a percentage of how much water contained in the simplicia.

Ash content was established by inserting 2 grams of dried simplicia into a crucible, and then put it in a kiln at a temperature of $700^{\circ} \mathrm{C}$ until it becomes ashes. After that, cool it down and weighed it to constant weight.

$$
\text { Total_ash }=\frac{\text { Weight_of_ash }}{\text { Initial_Weight_of_Simplicis }} \times 100 \%
$$

\section{B. Padina australis Extract Establishment}

Padina australis utilized in this research was made by using a modified version of the research conducted by [9]-[10]. 250 grams of Padinaaustralis simplicia was put inside a brown bottle, then a solvent is added until its volume reached $1000 \mathrm{ml}$ with a ratio of 1:4 (weight/volume). The extraction procedure was done by soaking the sample with $96 \%$ ethanol. The result of maceration was then filtered using Whatman 42 filter paper to get the filtrate and residue. The soaking process was done 3 times until the filtrate appears to be clear. Concentration of the obtained filtrate was then increased by using a rotary vacuum evaporator at a temperature of $400^{\circ} \mathrm{C}$ to obtain a crude extract (crude extract) in the form of a paste or also known as the viscous extract. The yield (amount of reactant obtained through chemical reaction) of the extract is calculated by comparing simplicia extract's initial weight and final weight.

Yield_Extract $=\frac{\text { The_Weight_of_Obtained_Extract }}{\text { Simplicia's_Initial_Weight }} \times 100 \%$

\section{Phytochemical Test of Padina australis Extract}

Phytochemical test was conducted to identify chemical compound and to determine the classification of the active compound inside Padina australis extract in ethanol $96 \%$. Phytochemical test was conducted on alkaloids test, tannins test, steroids/ triterpenoids test, saponins test, and phenol test [11]-[12].

\section{Active Compound Test using GC-MS Method}

GC-MS Method is used to analyze the identified active compounds in P.australis. Padina australis extract samples in $96 \%$ ethanol solvent were analyzed by using GC-MS instrument Agilent 5975C to determine the organic compounds inside. GC-MS activity test results show there are 121 compound that has antibacterial activity, including terpenoids, triterpenoids, and pythol.

\section{E. Toxicity Test of Padina australis Extract Using BSLT Method}

Toxicity test was conducted based on the method of [13]-[14], with Artemia salina larvae as test animals. A. salina eggs were first incubated in artificial seawater ( $38 \mathrm{~g}$ of salt in a $1000 \mathrm{ml}$ water) under a 20watt fluorescent lamp. After 48 hours the eggs hatch into nauplii instar III / IV and ready to be used as test animals. The larvae of $A$. salina then inserted into the vial which already contains a sample extract solution with 50, 100, and 500 doses of the series, and 1000 ppm with three replications. All the vials were incubated at room temperature for 24 hours under the light of a 20 watt fluorescent lamp. Observations were conducted after 24 hours to see the number of dead Artemia salina at each concentration. LC50 value in $\mathrm{ug} / \mathrm{ml}$ or $\mathrm{ppm}$ was determined by using probit analysis with MINITAB version 13.2 software with $95 \%$ confidence interval [15].

\section{RESULT}

\section{A. Moisture Concentration and Ash Content of Padina australis}

The amount of Padina australis obtained directly from Banten Bayah Coastal waters in wet form was $2 \mathrm{~kg}$. Padina australis was dried under direct sunlight for five days. After being dried, the amount of Padina australis simplicia that was obtained is 250 grams. This means it has $83.33 \%$ drying shrinkage. Ash content was determined by using a furnace. The ash content of Padina australis simplicia that was obtained is $14.53 \%$, and is a higher value than the result in the research conducted by [10] at $5.50 \%$.

\section{B. Phytochemical Test Result}

Phytochemical test result of dry Padina australis extract in ethanol $96 \%$ showed positive result in triterpenes, alkaloids, tannins, phenols, quinone and saponin group with qualitatively good result.

\section{Active Compound Test Result using GC-MS Method}

Testing dry Padina australis extract in $96 \%$ ethanol using GC-MS method is the next stage to identify the compound present in the sample. The compound listed in Table 1 is the compound that has similarity percentage ranges between 90-99\%.

\section{Analysis of Toxicity Extract Using BSLT}

The toxicity test results of Padina australis extract in ethanol $96 \%$ to shrimp larvae is obtained by counting the number of dead shrimp larvae. By knowing the number of dead larvae, $\mathrm{LC}_{50}$ value can be calculated by conducting probit analysis. $\mathrm{LC}_{50}$ is concentration of a substance that can cause death to $50 \%$ population of test animals.

Table 1. Identification Result of Active Compound In Padina australis

\begin{tabular}{|c|c|c|c|c|c|c|}
\hline No & $\begin{array}{c}\text { Name of } \\
\text { Compound }\end{array}$ & $\begin{array}{c}\text { Retention } \\
\text { Time } \\
\text { (minutes) }\end{array}$ & $\%$ Area & Devolution & $\begin{array}{c}\text { Molecular } \\
\text { Weight }\end{array}$ & Structure \\
\hline 1 & Phytol & 11.962 & 2.13 & 91 & 296.31 & \\
\hline
\end{tabular}




\section{DISCUSSION}

\section{A. Moisture Concentration and Ash Content of Padina australis}

The obtained moisture concentration of Padina australis at the temperature of $105^{\circ} \mathrm{C}$ is $6.68 \%$. This is almost equal to the value in the research conducted by [16], which is $6.4 \%$ extraction of Padina australis is conducted by maceration method using ethanol $96 \%$.

The amount of dry Padina australis extract in ethanol $96 \%$ obtained through that method is 26.72 grams. The amount obtained is used to calculate the amount of yield extract. The obtained amount of yield extract of dry Padina australis extract in ethanol $96 \%$ is $10.68 \%$. This indicates that Padina australis contains bioactive components which tend to dissolve in polar solvents. The process of extracting some herbal plants using different solvents conducted by [17] produced the highest yield in polar solvents. The magnitude of the yield extract shows that a large number of active components are being extracted by the compound during the maceration process. This is similar to the report of [18] that the high yield value indicates the number of bioactive components.

\section{B. Phytochemical Test}

These results are consistent with the research of [19]-[20] who argued that the phytochemical compounds detected in Padina australis extract-alkaloids, phenols, steroids, triterpenoids, tannins and saponins- are effective as an antibacterial and antifungal.

\section{Active Compound Test Using GC-MS Method}

Active compound test of Padina australis extract in $96 \%$ ethanol by using GC-MS method produces 17 compounds. The test result of positive activity against dry extract Padina australis in ethanol $96 \%$ is the activity as an antibacterial namely class terpenoids, alkaloids, and steroids. Terpenoids compounds that have antibacterial activity are monoterpenoid, linalool, diterpenoid, phytol, triterpenoids, and saponins [21]-[23]. Based on the previous pythochemical test results, the possible compounds contained in the sample are terpenoids, phenolics, saponins, alkaloids, and tannins. The GC-MS test indicates that the sample containing 96\% ethanol has a good concentration of terpenoids, saponins, alkaloids, phenolics, steroids and fatty acids, from all of the possible compounds found in the sample.

\section{Analysis of Toxicity Extract Using BSLT}

This research shows that $\mathrm{LC}_{50}$ value of Padina australis extract samples with $96 \%$ ethanol is $177.83 \mathrm{ug} / \mathrm{ml}$. [24], explained that chemical compound is potentially bioactive if it has $\mathrm{LC}_{50}$ values less than $1000 \mathrm{pg} / \mathrm{ml}$, and has potential as an antibacterial when it is less than $200 \mathrm{ug} / \mathrm{ml}$. Therefore, Padina australis extract in $96 \%$ ethanol can be said to have potential as an antibacterial.

\section{CONCLUSION}

The phytochemical test of dry Padina australis extract in 96\% ethanol shows strong positive results in triterpenoid, and shows that Padinaaustralis is effective as an antibacterial.

The Active compound test of Padina australis extract in $96 \%$ ethanol by using GC-MS method produces 17 compounds and compounds suspected phytol potential as antibacterial.

$\mathrm{LC}_{50}$ value obtained through toxicity test of Padina australis extract samples in $96 \%$ ethanol by utilizing BSLT method is $177.83 \mathrm{gr} / \mathrm{ml}$. Therefore, Padina australis extract in $96 \%$ ethanol can be said to have potential bioactivity as an antibacterial.

\section{ACKNOWLEDGMENT}

A big thank intended to Kemenristekdikti which has funded this fundamental research grants for 2 years through DIPA 2014 and 2015.

\section{REFERENCES}

1. L. Goldberg,. Functional Food, Designer Food, Pharma Food, Neutraceuticals. New York: Chapman and Hall, 1984.

2. A. Rasyid. "Beberapa catatan tentang alginat." Osena, vol. 30, no. 1, pp. 9-14, 2005

3. T. S. Haryani and Triastinurmiatiningsih. Pengembangan Formula Tablet Ekstrak Padina austra-lis Sebagai Antibakteri Escherichia coli Penyebab Penyakit Diare. Report Research, Jakarta: Kemenristek Dikti, 2014

4. A. Susanto, Kandungan Sumber Daya Hayati Alga Coklat. Jakarta: Gramedia, 2008.

5. K. N. Kim, S. J., Heo, W. J. Yoon, S. M. Kang, G. Ahn, T. H. Yi, and Y. J. Jeon. "Fucoxanthin in-hibits the inflammatory response by suppressing the activation of NF- $\mathrm{BB}$ and MAPKs in lipopolysac-charide-induced RAW 264.7 macrophages." European Journal Pharmacology,vol. 649, no. 1, pp. 369-375, 2010.

6. L. Limantara and H. Heriyanto, "Studi Komposisi Pigmen dan Kandungan Fukosantin Rumput Laut Cokelat dari Perairan Madura dengan Kromatogra Cair Kinerja Tinggi.” Ilmu Kelautan: Indonesian Journal of Marine Sciences, vol. 15, no. 1, pp. 23-32, 2012.

7. A. V. Krishnaraju, T. V. N. Rao, D. Sundararaju, M. Vanisree, H. S. Tsay and G. V. Subbaraju. "Assessment of Bioactivity of Indian Medicinal Plants Using Brine Shrimp (Artemia salina) Lethality Assay." International Journal of Applied Science and Engineering, vol. 3, no. 2, pp. 125-134, 2005

8. S. R. Tamat, T. Wikanta and L. S. Maulina. "Aktivitas Antioksidan dan Toksisitas Senyawa Bioak-tif dari Ekstrak Rumput Laut Hijau Ulva reticulata Forsskal.” Jurnal Ilmu Kefarmasian Indonesia, vol. 5 , no. 1, pp. 31-36, 2007.

9. D. Juniarti, Osmeli and Yuhernita. "Kandungan Senyawa Kimia, Uji Toksisitas, (Brine Shrimp Lethality Test) dan Antioksidan (1,1-diphenyl- 2 pikrilhydrazyl) dari Ekstrak Daun Saga (Abrus preca-torius 1.).” Makara Sains, vol. 13 , no. 1, pp. 50-54, 2009

10. J. Santoso, S. Anwariyah, R. O. Rumiantin, A. P. Putri, N. Ukhty and Y. Yoshie- Stark. "Phenol Content, Antioxidant Activity and Fibers profile of Four Tropical Seagrasses from Indonesia." Journal of Coastal Development, vol. 15, no. 2, pp. 189-196, 2012.

11. S. V. Bhat, B. A. Nagasampagi and S. Meenakshi. Natural Product Chemistry and Application. New Delhi: Narosa Publishing House, 2009.

12. J. B. Harborne. "Metode Fitokimia: Penuntun Cara Modern Menganalisis Tumbuhan.” Bandung: Institut Teknologi Bandung, 1987.

13. B. N. Meyer, N. R. Ferrigni, J. E. Putman, L. B. Jacbsen, D. E. Nicols and J. L. McLaughlin. "Brine Shrimp: A Comvenient general Bioassay for Active Plant Constituents." Planta Medica, vol. 45, no 5, pp. 31-34, 1982. 
14. J. L. McLaughlin and L. L Rogers. "The use of biological assay to evaluate botanicals.” Drug Information Journal, vol. 32, no. 2, pp 513-24, 1998.

15. N. A. Zakaria, D. Ibrahim, S. F. Sulaiman and A. Supardy. "Assessment of antioxidant activity, total phenolic content and in-vitro toxicity of Malaysian red seaweed, Acanthophora spicifera." Journal Chemical and Pharmaceutical Research, vol. 3, no. 3, pp. 182-191, 2011.

16. Fitrya,"Pemeriksaan Karakter Simplisia Alga Padina australis Hauck (Dyctotaceae)" Jurnal Penelitian Sains, vol. 13, no. 3, pp. 46-49, 2010.

17. E. Suryanto, F. Wehantou and S. Raharjo. "Aktivitas penstabilan senyawa oksigen reaktif dari beberapa herbal." Jurnal Obat Bahan Alam, vol. 7, no. 1, pp. 62-68, 2008

18. T. Nurhayati and A. D. Nurjanah. "Kajian awal potensi ekstrak spons sebagai antioksidan.” Jurnal Kelautan Nasional, vol. 2, no. 2, 43-51, 2009

19. P. Fitriany. Kandungan Fenol, Senyawa Fitokimia, Aktivitas Antioksidan Rumput Laut Padina australis. Bogor. Bogor: Institut Pertanian Bogor, 2012,

20. A. G. Suganda, S. Swandari., R. Dewi, R. H. Sukmawan, L. Maeka and A. L. Ratna. Telaah Kandungan Kimia Padina australis Hauck (Dyctotacae). Bandung: Sekolah Farmasi ITB, 2007.

21. D. H. Grayson. "Monoterpenoids." Natural Product Reports, vol. 5, no. 5 , pp. 419-464, 1988.

22. A. K. Bigham, T. A. Munro, M. A., Rizzacasa and R. M. Robins-Browne. "Divinatorins A- C, New Neoclerodane Diterpenoids from the Controlled Sage Salvia d ivinorum." Journal of natural products, vol. 66, no. 9, pp. 1242-1244, 2013

23. S. Y. Lim, M. Meyer, R. A. Kjonaas and S. K. Ghosh. "Phytol-based novel adjuvants in vaccine formulation: 1 . assessment of safety and efficacy during stimulation of humoral and cell-mediated immune responses." Journal of immune based therapies and vaccines, vol. 4 no. 1, pp. 6-15, 2006.

24. A. Restasari, D. Kusrini and E. Fachriyah. Isolasi dan identifikasi Fraksi Teraktif dari Ekstrak Kloroform Daun Ketapang (Terminalia catappa Linn). Semarang: FMIPA Kimia UNDIP, 2009. 